\title{
SYNERGIC CARCINOSTATIC EFFECTS OF ASCORBIC ACID AND HYPERTHERMIA ON EHRLICH ASCITES TUMOR CELL
}

\author{
Y. Saitoh ${ }^{1 *}$, T. Yoshimoto ${ }^{1}$, S. Kato ${ }^{2}$, N. Miwa $^{3}$ \\ ${ }^{1}$ Laboratory of Bioscience \& Biotechnology for Cell Function Control, Faculty of Life and Environmental \\ Sciences, Prefectural University of Hiroshima, 562 Nanatsuka, Shobara, Hiroshima 727-0023, Japan \\ ${ }^{2}$ Radioisotope Facilities for Medical Science, Life Science Research Center, Mie University, \\ 2-174 Edobashi, Tsu, Mie 514-8507, Japan \\ ${ }^{3}$ Department of Radiological Technology, Faculty of Health Sciences, Butsuryo College of Osaka, \\ 3-33 Ohtorikita-machi, Sakai, Osaka 593-8324, Japan
}

\begin{abstract}
Aim: In this study, we evaluated the carcinostatic effects of combined ascorbic acid (AsA) and a capacitive-resistive electric transfer (CRet) hyperthermic apparatus-induced hyperthermic treatment on Ehrlich ascites tumor (EAT) cells. Materials and Methods: EAT cells were exposed to various AsA (0-10 mM) concentrations for $1 \mathrm{~h}$; they subsequently underwent CRet treatment for $15 \mathrm{~min}$ at $42^{\circ} \mathrm{C}$. Cell viability was assessed by the WST-8 assay $24 \mathrm{~h}$ after the combined treatment. Reactive oxygen species involvement was evaluated using catalase and tempol; caspase-3/7 activation was determined by their fluorescent substrates; cell proliferation were estimated by time-lapse observation. The effect on the cell cycle was analyzed by flow cytometry. Results: Combined AsA and CRet treatment synergistically suppressed cell viability compared with either treatment alone, and these synergistically carcinostatic effects were evident even at noncytotoxic concentrations of AsA alone $(\leqslant 2 \mathrm{mM})$. The carcinostatic effects of combined AsA and CRet treatment were attenuated in a dose-dependent manner by catalase addition, but not by the superoxide anion radical scavenger tempol. Time-lapse observation revealed that combined AsA and CRet treatment activated caspase-3/7 at 10-24 h after treatment, accompanied by significant cell growth suppression. Cell cycle analysis revealed that the rate of sub-G1-phase (apoptotic) cells was drastically increased at $12 \mathrm{~h}$ and $24 \mathrm{~h}$, and that the G2/M-phase cells gradually increased at 6-24 h after treatment. Conclusion: These results indicate that combined AsA and CRet treatment synergistically inhibits EAT cell growth through G2/M arrest and apoptosis induction via $\mathrm{H}_{2} \mathrm{O}_{2}$ generation at lower AsA concentrations; this carcinostatic effect cannot be exerted by AsA alone.
\end{abstract} Key Words: L-ascorbic acid, CRet system, hyperthermic action, Ehrlich ascites tumor cell, carcinostatic effect.

Ascorbic acid (AsA) acts as both an antioxidant and a pro-oxidant. Typically, it exhibits pro-oxidant properties at high concentrations [1] and in the presence of catalytic metal ions, such as iron and copper ions [2]. High doses of AsA (millimolar concentrations) reportedly inhibit the proliferation of various cancer cell lines [3], and the anticancer effect is exerted via $\mathrm{H}_{2} \mathrm{O}_{2}$-mediated, pro-oxidant mechanism [3-5]. Recently, the high-dose AsA treatment has been known as pharmacological AsA, which could be achieved through parenteral administration, such as intravenous infusion; the effects of pharmacological AsA on tumor growth in animals have also been confirmed in various cancer models, including xenografts [5-10]. Furthermore, it was demonstrated that high (pharmacologic), but not low (physiologic) AsA concentrations killed cancer cells but not normal cells, with cell death dependent on extracellular AsA concentrations [3, $4,6,11]$. Based on these studies, pharmacologic AsA is expected to be a more harmless antitumor approach with regard to complementary and alternative medicine. In addition to these effects of pharmacologic AsA, it has also been reported that it can increase the efficacy of several chemotherapeutic drugs and radiotherapy [12-14],

Submitted: March 5, 2015.

*Correspondence: $\quad$ E-mail: ysaito@pu-hiroshima.ac.jp

Tel.: +81 824741757

Fax: +81 824741757

Abbreviations used: AsA - ascorbic acid; CRet - capacitive-resistive electric transfer; EAT - Ehrlich ascites tumor; ROS - reactive oxygen species. and the usage of some agents appears to decrease with simultaneous usage of AsA [15]. Therefore, the appropriate combination of high-dose AsA and conventional anticancer therapeutic strategies may have the potential to improve outcomes compared with the treatment alone.

Capacitive-resistive electric transfer (CRet) system applies electric currents at frequencies within the $0.4-0.6 \mathrm{MHz}$ range to treatment of inflammation and musculoskeletal injuries [16-19]. It has been demonstrated that CRet system, which can produce electric stimuli and thermal effects simultaneously in tissues, can induce synergistically cytostatic and/ or cytotoxic effects in tumor tissues [20, 21]. Thus, CRet system has been studied as one of a novel application in the field of oncology. However, the effect of combined treatment with high-dose AsA and CRet treatment has not yet been investigated.

In this study, we investigated the carcinostatic effects of combined high-dose AsA and CRet treatment in Ehrlich ascites tumor (EAT) cells. Our results indicate that lower concentration of AsA combined with CRet synergistically inhibits the growth of EAT cells through $\mathrm{G} 2 / \mathrm{M}$ arrest and apoptosis induction via $\mathrm{H}_{2} \mathrm{O}_{2}$ generation.

\section{MATERIALS AND METHODS}

Cell culture. EAT cells (RCB0142) were obtained from the RIKEN BRC through the National Bio-Resource Project of the MEXT in Japan. Cells were cultured in Dulbecco's modified Eagle's medium (DMEM; Nissui Seiyaku, Tokyo) supplemented with $10 \%$ heat-inactivated 
fetal bovine serum (FBS, Biological Industries Ltd., Beit Haemek, Israel) and $4 \mathrm{mM} \mathrm{L-glutamine} \mathrm{at} 37^{\circ} \mathrm{C}$ in a humidified atmosphere of $95 \%$ air and $5 \% \mathrm{CO}_{2}$.

Cell viability. Cell viability was assessed on the basis of the intracellular enzymatic conversion of WST-8 to orange formazan, which is indicative of cell viability. Briefly, cells were rinsed with phenol red-free medium and incubated for $3 \mathrm{~h}$ in phenol red-free DMEM containing $10 \%$ of cell-counting kit- 8 reagent (Dojindo Laboratories, Kumamoto, Japan) at $37^{\circ} \mathrm{C}$. Absorbance at $450 \mathrm{~nm}$ was measured using a microplate reader (FLUOstar Optima; BMG Labtech, Offenburg, Germany). Cell viability was expressed as the percentage of absorbance relative to that of the control cells.

CRet system. CRet system can induce local hyperthermia induced in the target tissues through the mobile electrodes for transdermal application, and the treatment has been reported to be more effective and less edema formation than other thermal therapies [16]. Preliminary tests of CRet system on cancer patients also showed consistent signs of slowing down the growth of the tumor tissues without adverse effects in the surrounding healthy tissues [20,21]. Additonally, previous studies have shown that CRet treatment induces cytostatic effects in the human hepatocarcinoma HepG2 [16, 17, 19], cytotoxic effects in NB69 human neuroblastoma cells [18] and significantly potentiate anticancer effect of 6-O-palmitoyl-ascorbate on human tongue squamous carcinoma HSC-4 [22].

AsA and CRet treatment. EAT cells were seeded and preincubated for $24 \mathrm{~h}$, and subsequently treated with medium containing $0.1-10 \mathrm{mM}$ AsA, which was titrated with $\mathrm{NaOH}$ at $\mathrm{pH} 6.8-7.4$, for $1 \mathrm{~h}$ to mimic the clinical intravenous infusion of AsA [23]. For CRet treatment, we used a CRet signal generator (INDIBA DH-308; INDIBA S.A., Barcelona, Spain), which produces the electric currents of $0.45 \mathrm{MHz}$ and thermal effects synergistically in tissues [22, 24]. Exposure to CRet electric currents was achieved using pairs of stainless-steel electrodes designed ad hoc for in vitro stimulation (Fig. 1), as previously described [16-19, 22, 24].

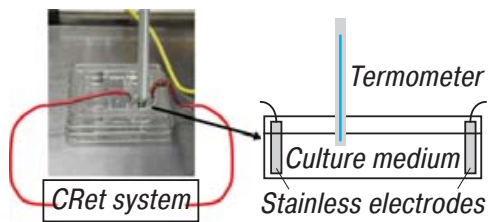

Fig. 1. Diagram of CRet exposure system for in vitro study. The pairs of stainless electrodes were inserted in a well and conducted to Cret system (apparatus), and temperature of the culture medium was monitorned in the well

The electrodes were inserted into each well or dish and connected in series to a CRet signal generator. The signal parameters of CRet system were monitored throughout exposure. Temperature of the culture medium reached to $42^{\circ} \mathrm{C}$ for approximately 2 min and kept for the established period under constant observation with thermometer. After AsA treatment for $1 \mathrm{~h}$, cells underwent CRet treatment for $15 \mathrm{~min}$ at $42^{\circ} \mathrm{C}$ or sham treatment without electric current; subsequently the media were exchanged with fresh media. After incuba- tion for further $24 \mathrm{~h}$ at $37^{\circ} \mathrm{C}$, cell viability was determined using the WST-8 method.

Caspase-3/7 activity assay. Caspase- $3 / 7$ activation in individual cells was detected using CellEvent ${ }^{\mathrm{TM}}$ caspase-3/7 Green (Life Technologies, CA, USA). Cells were seeded into a glass-bottomed, 35-mm dish (Matsunami Glass Ind., Ltd., Osaka, Japan) for 24 h. After combined AsA and CRet treatment, CellEvent ${ }^{\mathrm{TM}}$ caspase-3/7 Green solution was added to the dish that was subsequently placed in a BioStation IM (Nikon, Tokyo) and maintained at $37^{\circ} \mathrm{C}$ in a humidified atmosphere of $95 \%$ air and $5 \% \mathrm{CO}_{2}$ for time-lapse imaging. The fluorescence generated by activated caspase- $3 / 7$ was periodically observed with excitation and emission wavelengths of 485 and $535 \mathrm{~nm}$, respectively.

Cell cycle analysis. Cellswere centrifuged at $500 \mathrm{~g}$ for 5 min at $4^{\circ} \mathrm{C}$; and subsequently washed with phosphatebuffered saline (-). Next, cells were fixed and stained using a Cell Cycle Phase Determination kit (Cayman Chemical, MI, USA). The stained cells were analyzed by flow cytometry (Guava EasyCyte ${ }^{\mathrm{TM}}$; Merck Millipore, MA, USA).

Statistical analysis. Data are expressed as means \pm SD. Statistical comparisons were made using the unpaired Student's $t$-test or Dunnett's multiple comparisons test. A value of $p<0.05$ was considered statistically significant.

\section{RESULTS}

The suppressive effects of combined AsA and CRet treatment on cell viability in EAT cells. To evaluate the effects of combined AsA and CRet treatment on cell viability, we exposed EAT cells to various concentrations of AsA ( $0-10 \mathrm{mM})$ for $1 \mathrm{~h}$, and subsequently conducted CRet treatment for $15 \mathrm{~min}$ at $42{ }^{\circ} \mathrm{C}$. Cell viability was assessed $24 \mathrm{~h}$ after treatment. AsA treatment alone suppressed cell viability in a dose-dependent manner $(\geqslant 4 \mathrm{mM})$, whereas CRet treatmentalone elicited an approximately $42 \%$ decrease in cell viability (Fig. 2). Conversely, combined AsA and CRet treatment induced significant decreases in cell viability at AsA concentrations insufficient to elicit a suppressive effect on cell viability by itself $(0.1-4 \mathrm{mM})$. The effect of the combined treatment was also superior to that observed on using CRet alone with AsA concentrations over $1 \mathrm{mM}$. Furthermore, the combined treatment was more effective than the sum effects of AsA alone and CRet alone. These results indicate that combined treatment with AsA and CRet exerts a synergistically carcinostatic effect.

The influence of reactive oxygen species (ROS) on the suppressive effects of combined AsA and CRet treatment. We investigated whether ROS production was correlated with the suppressive effect on cell viability of combined treatment with AsA and CRet using the $\mathrm{H}_{2} \mathrm{O}_{2}$ scavenger catalase and the superoxide anion radical scavenger tempol [25]. Catalase attenuated the decrease in cell viability in a dose-dependent manner (Fig. 3), whereas tempol had no effect. These data suggest that $\mathrm{H}_{2} \mathrm{O}_{2}$ is responsible for the AsA- and CRet-induced anticancer effect in EAT cells, but not superoxide anion radicals. 

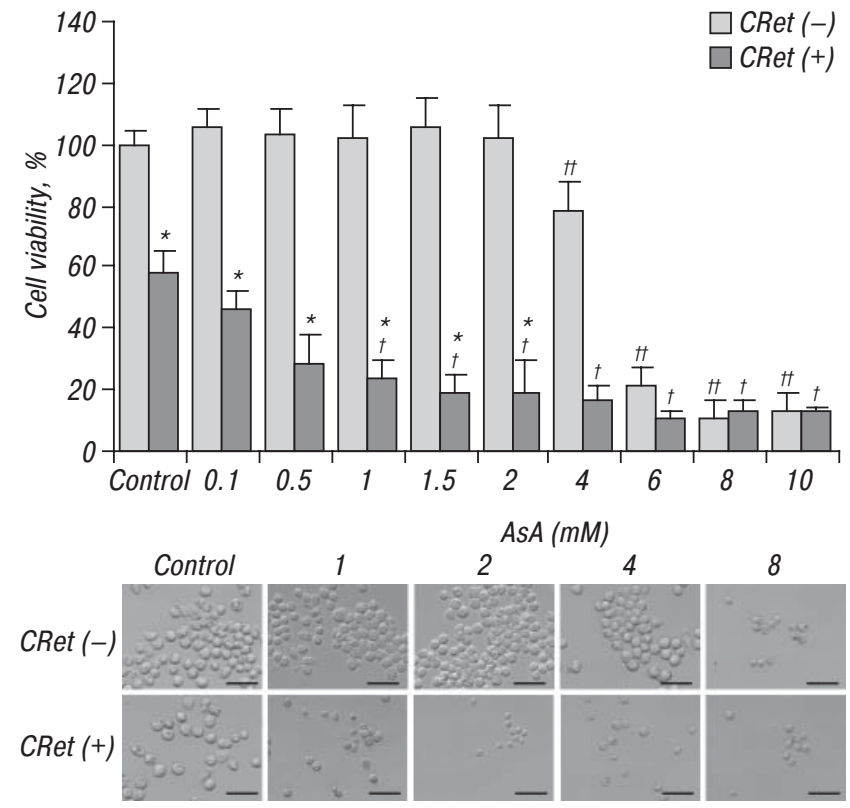

Fig. 2. The effects of combined AsA and CRet treatment on EAT cells. Cells were seeded at a density of $1.5 \times 10^{4}$ cells per well in a 24-well plate. After incubation for $24 \mathrm{~h}$, the cells were treated with medium containing $0-10 \mathrm{mM}$ of AsA for $1 \mathrm{~h}$ to which CRet was applied for 15 min at $42{ }^{\circ} \mathrm{C}$. A sham operation was conducted in a CRet (-) treatment group. Then, the culture media were exchanged with fresh media, and cells were incubated for $24 \mathrm{~h}$. Cell viability was assessed by the WST-8 assay. Results are expressed as mean $\pm \mathrm{SD}(n=3-18)$. Significantly different from the CRet $(-):{ }^{*} p<0.01$; significantly different from the CRet $(+)$ control: ${ }^{\dagger} p<0.01$; significantly different from CRet $(-)$ control: ${ }^{+t} p<0.01$. Scale bars $=50 \mu \mathrm{m}$
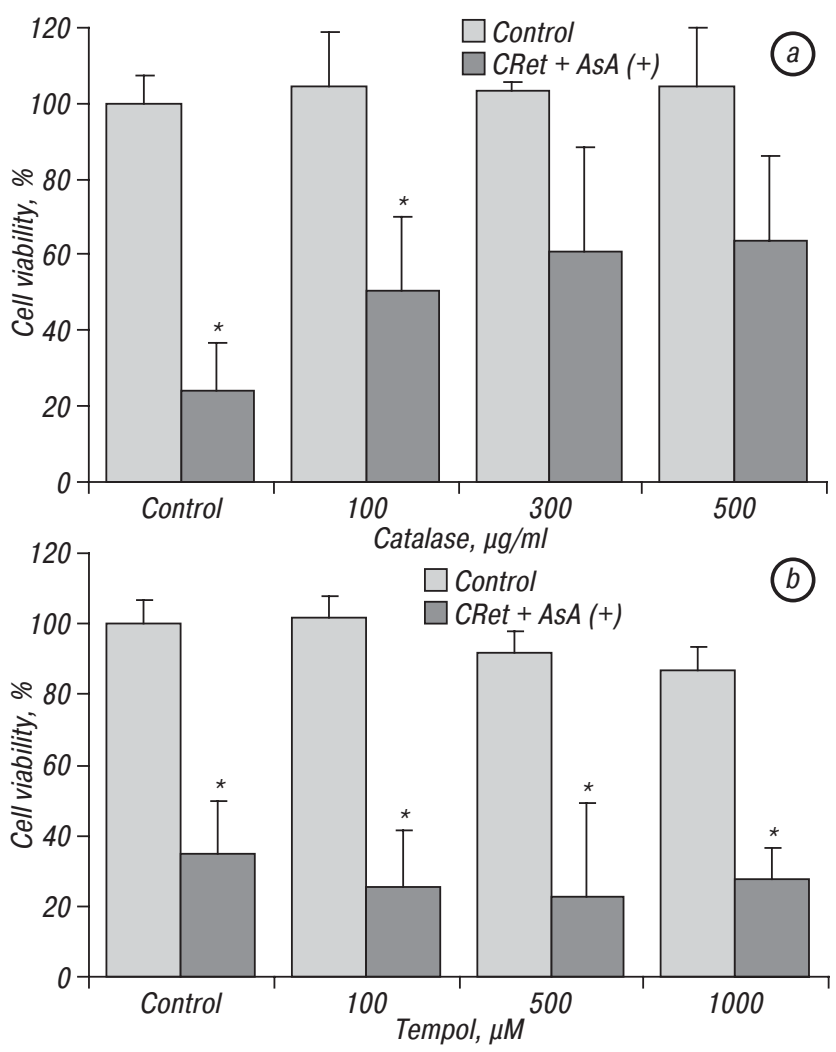

Fig. 3. The outcome of catalase or tempol treatment on the anticancer effects induced by combined AsA and CRet treatment. Cells were seeded at a density of $1.5 \times 10^{4}$ cells per well in a 24 -well plate. After incubation for $24 \mathrm{~h}$, the cells were treated with medium containing $2 \mathrm{mM}$ of AsA and catalase (a) or tempol $(b)$ for $1 \mathrm{~h}$, to which CRet was applied for $15 \mathrm{~min}$ at $42{ }^{\circ} \mathrm{C}$. Then, the culture media were exchanged with fresh media, and cells were incubated for $24 \mathrm{~h}$. Cell viability was assessed by the WST-8 assay. Results are expressed as mean $\pm \mathrm{SD}(n=3-6)$. Significantly different from the control: ${ }^{*} p<0.01$
Combined treatment with AsA and CRet induces apoptosis and inhibits cell growth. To elucidate whether the synergistic anticancer effects of combined AsA and CRet treatment are attributable to cell death or growth arrest, we observed cellular morphological changes using time-lapse apparatus and detected the activity of caspase-3/7 using its substrates. Control cells exhibited timedependent cell division during 24 h, but AsA- and CRettreated cells barely underwent cell division (Fig. 4, a). After incubation for $24 \mathrm{~h}$, the number of cells treated with AsA and CRet had decreased slightly relative to the number of cells at $0 \mathrm{~h}$ (immediately after AsA and CRet treatment), and it was significantly suppressed compared with that of the control (Fig. 4, b). Furthermore, green-stained activated caspase-3/7-positive cells observed $10 \mathrm{~h}$ after AsA and CRet treatment, gradually increased in a time-dependent manner (Fig. 4, a; in the dashed circles). These results suggest that combined treatment with AsA and CRet induces both apoptosis and growth inhibition, and that these effects play a pivotal role in their anticancer effects.

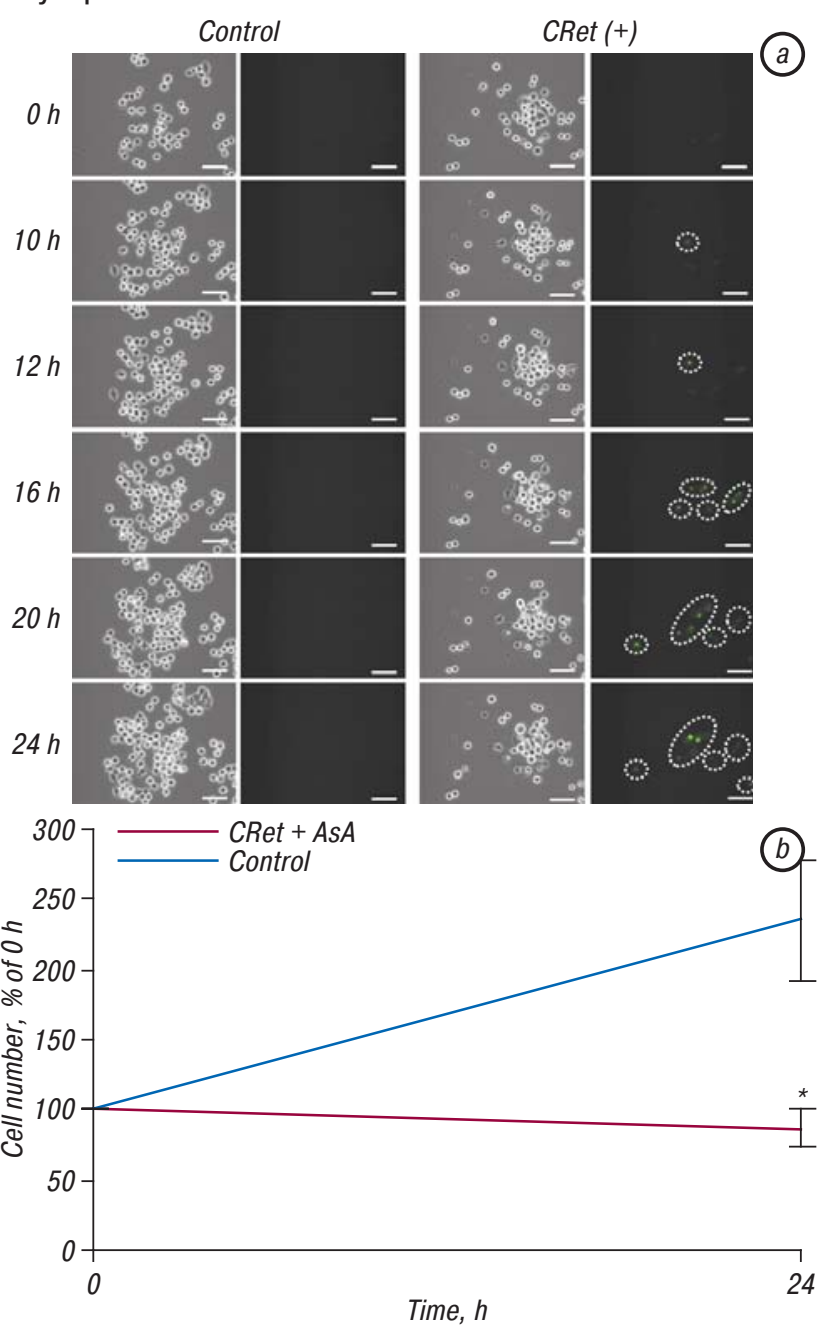

Fig. 4. The effects of combined AsA and CRet treatment on caspase- $3 / 7$ activation. Cells were seeded at a density of $7.6 \times 10^{4}$ cells in a glass-bottomed, $35 \mathrm{~mm}$-dish. After incubation for $24 \mathrm{~h}$, the cells were treated with medium containing $2 \mathrm{mM}$ of AsA for $1 \mathrm{~h}$ to which CRet was applied for $15 \mathrm{~min}$ at $42^{\circ} \mathrm{C}$. Then, the culture medium was exchanged with fresh medium, and cells were incubated in timelapse apparatus. Subsequently, morphologic changes of the cell and caspase-3/7 activation-induced green fluorescence were observed by time-lapse system for $24 \mathrm{~h}(a)$. Cell number was evaluated by counting the cells in three randomly selected fields $(b)$. Results are expressed as means $\pm \operatorname{SD}(n=3)$. Significantly different from the control: ${ }^{*} p<0.05$. Scale bars $=50 \mu \mathrm{m}$ 
The effects of combined AsA and CRet treatment on the cell cycle. As shown in Fig. 5, we analyzed the effects of combined AsA and CRet treatment on the cell cycle. After treatment, the proportions of sub-G1-, G1-, S-, and G2/M-phase cells were similar between the control and treated groups until $6 \mathrm{~h}$, but the proportion of sub-G1-phase (apoptotic) cells drastically increased from $2 \%$ at $6 \mathrm{~h}$ to $19.7 \%$ at $12 \mathrm{~h}$ and $6.5 \%$ at $24 \mathrm{~h}$ (see Fig. 5). Moreover, the proportion of G1-phase cells was markedly reduced, from $19.4 \%$ at $6 h$ to $10 \%$ at $12 h$ and $12.1 \%$ at $24 \mathrm{~h}$, whereas the proportion of $\mathrm{G} 2 / \mathrm{M}$-phase cells gradually increased from $41.7 \%$ at $6 \mathrm{~h}$ to $58 \%$ at $24 \mathrm{~h}$ following AsA and CRet treatment. These results support the theory that combined AsA and CRet treatment induces apoptosis and growth inhibition through G2/M arrest.
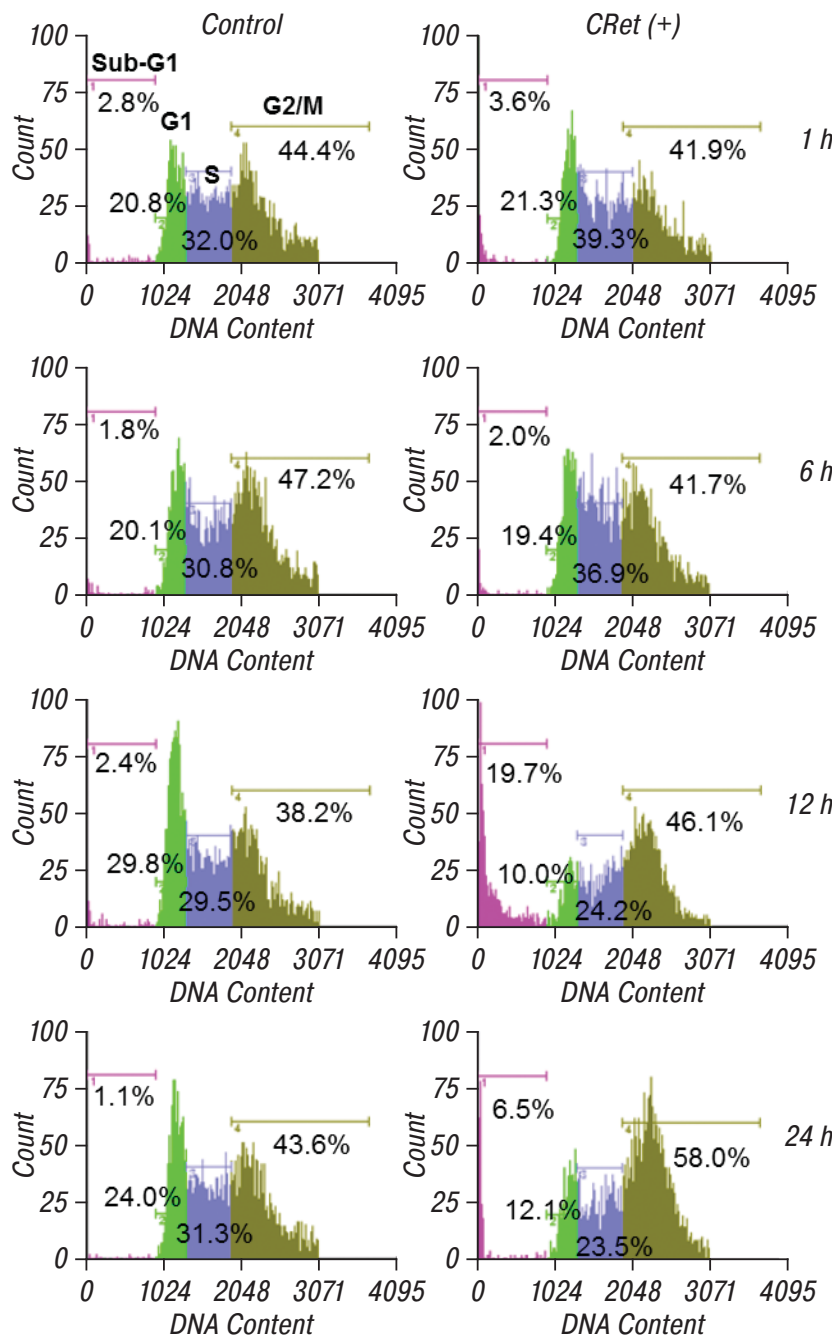

Fig. 5. The effects of combined AsA and CRet treatment on the cell cycle. Cells were seeded at a density of $7.6 \times 10^{4}$ cells in a $35-\mathrm{mm}$ dish. After incubation for $24 \mathrm{~h}$, the cells were treated with medium containing $2 \mathrm{mM}$ of AsA for $1 \mathrm{~h}$ to which CRet was applied for $15 \mathrm{~min}$ at $42^{\circ} \mathrm{C}$. Then, the culture media were exchanged with fresh media, and cells were cultured for up to $24 \mathrm{~h}$. At the indicated time, cells were treated with the Cell Cycle Phase Determination kit and analyzed by flow cytometry. For each sample, 5,000 cells were evaluated

\section{DISCUSSION}

In this study, we investigated the combined effect of pharmacologic AsA and CRet on the growth of EAT cells. Our results indicated that AsA alone decreased cell viability in a dose-dependent manner, and significantly reduced it at pharmacologic concentrations ( $\geqslant 4 \mathrm{mM})$.
Furthermore, CRet treatment alone $\left(42{ }^{\circ} \mathrm{C}, 15 \mathrm{~min}\right)$ also significantly decreased cell viability by approximately $42 \%$ compared with the cell viability on incubation at $37{ }^{\circ} \mathrm{C}$. We also found that combined AsA and CRet treatment significantly reinforced the suppression of cell viability compared with that of either treatment alone, and that the combination of lower concentrations of AsA and CRet elicited a synergistic effect. The enhanced suppressive effects of combined AsA and CRet treatment on cell viability were evident even at noncytotoxic concentrations of AsA. These results indicate that the combined use of AsA and CRet might offer a synergistically enhanced carcinostatic effect at lower AsA concentrations than the concentrations used in conventional pharmacologic AsA therapy [15, 26].

Thermal sensitization like hyperthermia has been demonstrated to induce an increase in ROS, such as superoxide anion radicals and $\mathrm{H}_{2} \mathrm{O}_{2}$, apoptosis [27, 28], and mitotic catastrophe, through alterations in the proteins that supportDNA metabolism [29, 30]. Additionally, it was also reported that pharmacologic concentrations of AsA kill cancer cells but not normal cells via $\mathrm{H}_{2} \mathrm{O}_{2}[3,4]$ and ascorbate radical generation [4], and that pharmacologic concentrations of AsA slow tumor growth [6, 31]. To investigate the mechanisms underlying the effect of combined treatment with lower concentrations of AsA and CRet, we first studied the involvement of superoxide anion radicals or $\mathrm{H}_{2} \mathrm{O}_{2}$. Catalase abrogated the decrease in cell viability elicited by combined AsA and CRet treatment in a dose-dependent manner, whereas the membranepermeable radical scavenger tempol did not induce a protective effect against the AsA- and CRet-induced reduction in cell viability (see Fig. 3 ). These results suggested that $\mathrm{H}_{2} \mathrm{O}_{2}$ generation, but not superoxide anion radicals, play a pivotal role in the carcinostatic effects of combined treatment with AsA and CRet. It has been established that $\mathrm{H}_{2} \mathrm{O}_{2}$ is involved in the redox control of several physiologic processes, including cell proliferation and apoptosis [32, 33]. Furthermore, we previously reported that combined treatment with AsA and CRet increased ascorbate radical formation in HSC-4 cells [22]. Therefore, these results suggest that both $\mathrm{H}_{2} \mathrm{O}_{2}$ and ascorbate radical generation are related to the effects of combined treatment with AsA and CRet through cell growth suppression because of G2/M arrest and apoptosis induction (see Fig. 4 and 5).

It has been demonstrated that CRet system can induce synergistically cytostatic and/or cytotoxic effects in tumor tissues $[20,21]$. On the other hand, the cytostatic and/or cytotoxic effects of CRet treatment are also confirmed at subthremal doses of CRet current in the human hepatocarcinoma HepG2 [16, 17, 19] and NB69 human neuroblastoma cells [18]. These results indicate that the cytostatic and/or cytotoxic effects could be caused by CRet electric current itself. Furthermore, it has been reported that CRet electric stimulation at subthermal level induced cytostatic and/or cytotoxic effects via induction of cell cycle arrest in phases $S$ and $\mathrm{G} 1$ of the cell cycle mediated by changes in the expression of cyclins D1, A and B1 and of cyclin-dependent kinase inhibitor p27kip1, 
induction of cytodifferentiation and necrosis [17-19]. Thus, our results suggest that the carcinostatic effect resulting from combined AsA and CRet treatment may be related to an electric stimulus-induced carcinostatic and carcinotoxic function.

Pharmacologic AsA concentrations are safely achieved in humans by intravenous administration [6, 11]; high concentrations of AsA selectively kill various cancer cells, but not normal cells [3]. Therefore, the utilization of pharmacologic AsA is anticipated to become a prospective therapeutic anticancer treatment. In fact, high-dose parenteral AsA is currently administered to thousands of patients by practitioners of complementary and alternative medicine [15, 34]. Although intravenously administered high-dose AsA is considered to be a relatively innocuous and beneficial therapeutic approach for cancer therapy, concerns remain about its adverse effects [34-36]. Our results indicate that combined AsA and CRet treatment can induce a synergistically carcinostatic effect at nontoxic AsA concentrations. Therefore, our findings might provide a clue to mitigate adverse effects of pharmacologic AsA therapy. A previous study [3] demonstrated that normal cells were unaffected by $20 \mathrm{mM}$ AsA, whereas five of 10 cancer lines that were tested exhibited half-maximal effective concentration values of $<4 \mathrm{mM}$ following $1 \mathrm{~h}$ of AsA exposure. In our study, EAT cells were barely affected by AsA concentrations of $<4 \mathrm{mM}$; therefore, EAT cells appear comparatively AsA-resistant. Nevertheless, the combination of AsA and CRet exerted a markedly carcinostatic effect at noncytotoxic concentrations of AsA. Although additional investigations are necessary for better understanding of these efficacies especially in human-derived tumor cells and human, these results imply the possibility that the combination of AsA and CRet treatment can exert carcinostatic effects on pharmacologic AsA therapy-resistant tumor cells.

In conclusion, the AsA concentration necessary for carcinostatic effects can be reduced by its combination with CRet-induced CRet, and this combined treatment with low-concentration AsA $(\leqslant 2 \mathrm{mM})$ and CRet induces more marked and synergistically carcinostatic effects than either AsA or CRet treatment alone. Moreover, our results demonstrate that these carcinostatic effects occurred through the induction of apoptosis and the suppression of cell proliferation because of $\mathrm{G} 2 / \mathrm{M}$ arrest via $\mathrm{H}_{2} \mathrm{O}_{2}$ generation. As cancer therapies are often combinatorial, AsA in combination with CRet is worthy of further examination for the treatment of various types of tumor.

\section{ACKNOWLEDGEMENTS}

We thank Dr. K. Kageyama and Dr. R. Asada for their technical advice, and thank INDIBA-Japan, Tokyo, for technical assistance.

\section{REFERENCES}

1. Fan $X$, Reneker LW, Obrenovich ME, et al. Vitamin $\mathrm{C}$ mediates chemical aging of lens crystallins by the Mail- lard reaction in a humanized mouse model. Proc Natl Acad Sci USA 2006; 103: 16912-7.

2. Buettner GR, Jurkiewicz BA. Catalytic metals, ascorbate and free radicals: combinations to avoid. Radiat Res 1996; 145: $532-41$.

3. Chen Q, Espey MG, Krishna MC, et al. Pharmacologic ascorbic acid concentrations selectively kill cancer cells: action as a pro-drug to deliver hydrogen peroxide to tissues. Proc Natl Acad Sci USA 2005; 102: 13604-9.

4. Chen Q, Espey MG, Sun AY, et al. Ascorbate in pharmacologic concentrations selectively generates ascorbate radical and hydrogen peroxide in extracellular fluid in vivo. Proc Natl Acad Sci USA 2007; 104: 8749-54.

5. Du J, Martin SM, Levine M, et al. Mechanisms of ascorbate-induced cytotoxicity in pancreatic cancer. Clin Cancer Res 2010; 16: 509-20.

6. Chen Q, Espey MG, Sun AY, et al. Pharmacologic doses of ascorbate act as a prooxidant and decrease growth of aggressive tumor xenografts in mice. Proc Natl Acad Sci USA 2008; 105: 11105-9.

7. Verrax J, Calderon PB. Pharmacologic concentrations of ascorbate are achieved by parenteral administration and exhibit antitumoral effects. Free Radic Biol Med 2009; 47: 32-40.

8. Yeom CH, Lee G, Park JH, et al. High dose concentration administration of ascorbic acid inhibits tumor growth in BALB/C mice implanted with sarcoma 180 cancer cells via the restriction of angiogenesis. J Transl Med 2009; 7: 70.

9. Pollard HB, Levine MA, Eidelman O, et al. Pharmacological ascorbic acid suppresses syngeneic tumor growth and metastases in hormone-refractory prostate cancer. In Vivo 2010; 24: 249-55.

10. Takemura $Y$, Satoh M, Satoh $K$, et al. High dose of ascorbic acid induces cell death in mesothelioma cells. Biochem Biophys Res Commun 2010; 394: 249-53.

11. Hoffer LJ, Levine M, Assouline S, et al. Phase I clinical trial of i.v. ascorbic acid in advanced malignancy. Ann Oncol 2008; 19: 1969-74.

12. Ma Y, Chapman J, Levine M, et al. High-dose parenteral ascorbate enhanced chemosensitivity of ovarian cancer and reduced toxicity of chemotherapy. Sci Transl Med 2014; 6: 222 ra18.

13. Welsh JL, Wagner BA, van't Erve TJ, et al. Pharmacological ascorbate with gemcitabine for the control of metastatic and node-positive pancreatic cancer (PACMAN): results from a phase I clinical trial. Cancer Chemother Pharmacol 2013; 71: 765-75.

14. Shinozaki K, Hosokawa Y, Hazawa M, et al. Ascorbic acid enhances radiation-induced apoptosis in an HL60 human leukemia cell line. J Radiat Res 2011; 52: 229-37.

15. Levine M, Padayatty SJ, Espey MG. Vitamin $\mathrm{C}$ : a concentration-function approach yields pharmacology and therapeutic discoveries. Adv Nutr 2011; 2: 78-88.

16. Hernández-Bule ML, Trillo MA, Cid MA, et al. In vitro exposure to $0.57-\mathrm{MHz}$ electric currents exerts cytostatic effects in HepG2 human hepatocarcinoma cells. Int J Oncol 2007; 30: 583-92.

17. Hernández-Bule ML, Cid MA, Trillo MA, et al. Cytostatic response of HepG2 to $0.57 \mathrm{MHz}$ electric currents mediated by changes in cell cycle control proteins. Int J Oncol 2010; 37: 1399-405.

18. Hernández-Bule ML, Roldán E, Matilla J, et al. Radiofrequency currents exert cytotoxic effects in NB69 human neuroblastoma cells but not in peripheral blood mononuclear cells. Int J Oncol 2012; 41: 1251-9.

19. Hernández-Bule ML, Trillo MÁ, Úbeda A. Molecular mechanisms underlying antiproliferative and differentiating 
responses of hepatocarcinoma cells to subthermal electric stimulation. PLoS One 2014; 9: e84636.

20. Ley A, Cladellas M, Colet S, et al. Transferencia eléctrica capacitiva (TEC). Técnica no invasiva de hipertermia profunda en el tratamiento de los gliomas cerebrales. Resultados preliminaries. Neurocirugía 1992; 3: 118-23 (in Spanish).

21. Ley-Valle A. Hipertermia intracraneal no invasiva mediante la técnica de Transferencia Eléctrica CapacitivaTEC-(*). Resultados de la termometría cerebral e intratumoral. Neurocirugía 2003; 14: 41-5 (in Spanish).

22. Kato S, Asada R, Kageyama K, et al. Anticancer effects of 6-O-palmitoyl-ascorbate combined with a capacitiveresistive electric transfer hyperthermic apparatus as compared with ascorbate in relation to ascorbyl radical generation. Cytotechnology 2011; 63: 425-35.

23. Padayatty SJ, Sun H, Wang Y, et al. Vitamin C pharmacokinetics: implications for oral and intravenous use. Ann Intern Med 2004; 140: 533-7.

24. Kato S, Saitoh Y, Miwa N. Repressive effects of a capacitive-resistive electric transfer (CRet) hyperthermic apparatus combined with provitamin $\mathrm{C}$ on intracellular lipid-droplets formation in adipocytes. Int J Hyperthermia 2013; 29: 30-7.

25. Chatterjee PK, Cuzzocrea S, Brown PA, et al. Tempol, a membrane-permeable radical scavenger, reduces oxidant stress-mediated renal dysfunction and injury in the rat. Kidney Int 2000; 58: 658-73.

26. Parrow NL, Leshin JA, Levine M. Parenteral ascorbate as a cancer therapeutic: a reassessment based on pharmacokinetics. Antioxid Redox Signal 2013; 19: 2141-56.

27. Katschinski DM, Boos K, Schindler SG, et al. Pivotal role of reactive oxygen species as intracellular media- tors of hyperthermia-induced apoptosis. J Biol Chem 2000; 275: $21094-8$.

28. Hirano H, Tabuchi Y, Kondo T, et al. Analysis of gene expression in apoptosis of human lymphoma U937 cells induced by heat shock and the effects of alpha-phenyl N-tert-butylnitrone (PBN) and its derivatives. Apoptosis 2005; 10: 331-40.

29. Coss RA, Dewey WC, Bamburg JR. Effects of hyperthermia (41.5 degrees) on Chinese hamster ovary cells analyzed in motisis. Cancer Res 1979; 39: 1911-8.

30. Mackey MA, Ianzini F. Enhancement of radiationinduced mitotic catastrophe by moderate hyperthermia. Int J Radiat Biol 2000; 76: 273-80.

31. Verrax J, Calderon PB. Pharmacologic concentrations of ascorbate are achieved by parenteral administration and exhibit antitumoral effects. Free Radic Biol Med 2009; 47: 27-32.

32. Antunes F, Cadenas E. Cellular titration of apoptosis with steady state concentrations of $\mathrm{H}(2) \mathrm{O}(2)$ : submicromolar levels of $\mathrm{H}(2) \mathrm{O}(2)$ induce apoptosis through Fenton chemistry independent of the cellular thiol state. Free Radic Biol Med 2001; 30: 1008-18.

33. Cai H. Hydrogen peroxide regulation of endothelial function: origins, mechanisms, and consequences. Cardiovasc Res 2005; 68: 26-36.

34. Padayatty SJ, Sun AY, Chen Q, et al. Vitamin C: intravenous use by complementary and alternative medicine practitioners and adverse effects. PLoS One 2010; 5: e11414.

35. Verrax J, Calderon PB. The controversial place of vitamin C in cancer treatment. Biochem Pharmacol 2008; 76: 1644-52.

36. Chen X, Shen L, Gu X, et al. High-dose supplementation with vitamin $\mathrm{C}$-induced pediatric urolithiasis: the first case report in a child and literature review. Urology 2014; 84: 922-4. 